Int.J. Hum. Soc. Dev. Res.

ISSN (P):2521-1439; ISSN (E):2523-4331

Volume 3, № 1, 2019. 58-65

DOI: $10.30546 / 2523-4331.2019 .3 .1 .58$

\title{
APPLICATION OF JOB HAZARD ANALYSIS (JHA) ON WELDING PROCESS INSIDE REACTOR UNIT
}

\author{
Hakan ERDOGAN \\ Esenyurt University, Turkey
}

(C) The Author(s) 2019

\begin{abstract}
Every day many workers are injured and killed at the workplace. Job Hazard Analysis (JHA) helps to analysis to eliminate and prevent hazards. This is likely to result reducing of injuries and illnesses; safer, more effective work methods; reduced workers' compensation costs; and increased worker productivity. JHA is also useful for training new employees in the steps required to perform their jobs safely. JHA is applied, accidents or near-accidents have occurred, one or more of those involved in the job are not familiar with all hazards and/or how to protect against these hazards, A new team of workers are working together, safe execution of the work requires close cooperation and coordination between several people and new equipment or new processes are being introduced.This study aimed to show elimination of hazards on welding process using JHA . It provides to help incidents and possible accidents.

C2019.All rights reserved
\end{abstract}

ARTICLE HISTORY

Received: 20/11/2018

Accepted: $11 / 03 / 2019$

Published online: 01/04/2019

\section{KEYWORDS}

Safety, job, job safety analysis, hazards, welding 


\section{Introduction}

Job Hazard Analysis (JHA) is a method of analysis towards potential hazards in working place by analizing working system and working procedure as well as human as the workers( 1). It is a technique that focuses on job tasks as a way to identify hazards before they occur. It focuses on the relationship between the worker, the task, the tools, and the work environment. One of the best ways to determine and establish proper work procedures is to conduct a job hazard analysis. A job hazard analysis is one component of the larger commitment of a safety and health management system (2).

The JHA provides the basic methodology and structure needed to find out hazards. JHA application will enhance an organization's evaluation of hazards and their associated risks and should be an essential fundamental part of any safety process (3). JHA requires supervisors to devote time to see work areas and to observing workers work. It is multistep process designed to study and analyse a task then break down that task into steps which provide a means of eliminating associated hazards (4).

The first step in preparing to conduct a JHA is to review all of the jobs in the workplace and make a list of those jobs that might require a JHA. The method uses a technique known as the SREDIM principle:

Select (work to be studied)

Record (how work is done)

Examine (the total situation)

Develop (best method for doing work)

Install (this method into the company's operations)

Maintain (this defined and measured method) (5).

The basic procedure for job safety analysis is as follows:

1 Select the job to be analysed. (SELECT)

2 Break the job down into its component parts in an orderly and chronological sequence of job steps. (RECORD)

3 Critically observe and examine each component part of the job to determine the risk of accident. (EXAMINE)

4 Develop control measures to eliminate or reduce the risk of accident. (DEVELOP) 5 Formulate written and safe systems of work and job safety instructions for the job. (INSTALL) 
6 Review safe systems of work and job safe practices at regular intervals to ensure their utilisation. (MAINTAIN)

JHA record chart uses for welding process shown at Table .1

\section{Table 1 : JHA record chart}

\begin{tabular}{|l|r|r|r|r|r|}
\hline \multicolumn{5}{|c|}{ Job Hazard Analysis Record Chart } \\
\hline Job & $:$ & \multicolumn{2}{|c|}{ Date } & $:$ & \\
\hline Analysed by & $:$ & & Date & $:$ & \\
\hline $\begin{array}{l}\text { Reviewed } \\
\text { by }\end{array}$ & & & Date & $:$ & \\
\hline $\begin{array}{l}\text { Approved } \\
\text { by }\end{array}$ & $:$ & \multicolumn{2}{|c|}{$\begin{array}{c}\text { Preventive } \\
\text { Measures }\end{array}$} \\
\hline \multicolumn{2}{|l|}{ Sequence of Tasks } & Potential Hazards & \multicolumn{3}{|c|}{} \\
\hline
\end{tabular}

JHA will include past accident and loss experience, maximum potential loss, probability of recurrence, legal requirements, the newness of the job and the number of employees at risk.

\section{Material and Method}

In this study we use JHA for welding process in reactor unit at Propane Dehydrogenation Unit (PDH). PDH is an industrial project in Tobolsk /Russia. It has contained earthworks infrastructure, construction, steel structures, mechanical and commissioning works (Figure 1) (6).

JHA Prerequisites are :

1. Establish JHA team

2. Select, define, and delimit the job to be analysed

3. Collect necessary background information

4. Select a suitable JHA worksheet

Jobs with the worst accident history have priority and should be analysed first. 




Figure 1 : Propane Dehydrogenation Unit (PDH) in Russia

Accident frequency: A job that has repeatedly caused accidents is a candidate for an immediate JHA.

Accident severity: Every job that has produced a lost time injury (LTI) or required medical treatment should be analysed.

Accident potential: Every job with a potential for a severe accident should be analysed

New jobs, non-routine jobs, or job changes: These are also prime candidates for JHA.

Routine jobs: Routine jobs with inherent hazards that the worker is exposed to.

The following information about the job should be provided:

- A summary description of the job and the purpose of the job.

- A preliminary job review (e.g., observation of the job and the location made by the team leader). The review report may preferably be supplemented by photos and video.

- A listing of required training for access to the work location, to operate equipment/vehicles, to work at heights, etc.

-A listing of required/recommended personal protective equipment against hazards when performing the job in the specified location. 
Before the analysis is started, collection of information may be necessary

- Interviews

- Written procedures

- Manuals

- Observation of execution of work steps

- Review of reports from accidents and incidents

JHAs should be a team effort and normally involve more than one person. The most experienced person who performs that job should be on the team. This person has the most familiarity with the job, how it is performed, and any hazards associated with the job (7).

For our work JHA team has consisted as shown table

Table 2: JHA team members

\begin{tabular}{|l|l|l|}
\hline Team leader & Hakan Erdogan & HSE Manager \\
\hline Secretary & Rita Glatman & Office staff \\
\hline Team & Yilmaz Simsek & HSE Inspector \\
members & Tufan Ismailoglu & \\
& Yusuf Dulger & \\
\cline { 2 - 3 } & Hamit Canpolat & Welding foreman \\
\hline
\end{tabular}

Before welding process in reactor unit, JHA team considered to methodology. Welding procedures, legal regulations, interview with welding workers, review of reports from accidents and incidents are reconnoitred. After analysed, we have gotten table 3 .

Table 3: Definition of basic welding hazards with using JHA chart

\begin{tabular}{|c|c|c|c|c|c|c|}
\hline \multicolumn{7}{|c|}{ Job Hazard Analysis Record Chart } \\
\hline Job & : & & \multicolumn{4}{|c|}{ Welding process inside reactor unit } \\
\hline Analysed by & $:$ & & $\begin{array}{ll}\mathrm{JHA} & \text { team } \\
\text { members } & \end{array}$ & Date & : & 11.09 .2013 \\
\hline Reviewed by & $:$ & & Can Aydin & Date & $:$ & 12.09 .2013 \\
\hline Approved by & : & & Ozgur Ayavefe & Date & : & 16.09 .2013 \\
\hline \multirow[t]{2}{*}{$\begin{array}{c}\text { Sequence of } \\
\text { Tasks }\end{array}$} & $\begin{array}{l}\text { Poten } \\
\text { Haza }\end{array}$ & & \multicolumn{4}{|c|}{ Preventive Measures } \\
\hline & & & \multicolumn{4}{|c|}{$\begin{array}{l}\text {-Using suitable welding shields and goggles } \\
\text { - Suitable fire resistant overalls andg loves are } \\
\text { provided and used to protect the skin against burns } \\
\text { from hot surfaces, flames, sparksand uv radiation. } \\
\text { - Working combustible materials and waste are kept }\end{array}$} \\
\hline
\end{tabular}

Int.J. Hum. Soc. Dev. Res. Volume 3, № 1, 2019.58-65 


\begin{tabular}{|c|c|c|}
\hline $\begin{array}{l}\text { Hot Work } \\
\text { and rocesses }\end{array}$ & $\begin{array}{l}\text { Fire and } \\
\text { explosions }\end{array}$ & $\begin{array}{l}\text { in covered containers. } \\
\text { - Welding benches are constructedfrom non- } \\
\text { flammable and heat resistant material to prevent } \\
\text { fires. } \\
\text { - Know where the fire alarms and extinguishers are } \\
\text { located, and check the extinguisher's gauge to make } \\
\text { sure it is full. } \\
\text { - Welding area is restricted to authorized and } \\
\text { qualified persons only. } \\
\text { - All workers are provided with and use a flexible } \\
\text { extraction arm for welding activities. } \\
\text { - Gas cylinders are securely stored in a designated } \\
\text { area. } \\
\text { - Gas welding torches and hoses and regularly } \\
\text { checked and maintained to comply with russian } \\
\text { standards. }\end{array}$ \\
\hline $\begin{array}{l}\text { Hot Work } \\
\text { and rocesses }\end{array}$ & $\begin{array}{l}\text { Electric } \\
\text { Shock }\end{array}$ & $\begin{array}{l}\text {-Welding equipments and grounding circuits are } \\
\text { checked and tested regularly. } \\
\text { - Welding operators should wear dry gloves in good } \\
\text { condition, never touch the electrode or metal parts } \\
\text { of the electrode holder with skin or wet clothing and } \\
\text { be sure to insulate themselves from the work and } \\
\text { ground, keeping dry insulation between their body } \\
\text { and the metal being welded or ground (such as a } \\
\text { metal floor or wet surface). } \\
\text { - Welding operators also should inspect the } \\
\text { electrode holder for damage before beginning to } \\
\text { weld and keep the welding cable and electrode } \\
\text { holder insulation in good condition, because the } \\
\text { plastic or fiber insulation on the electrode holder } \\
\text { prevents contact with the electrically "hot" metal } \\
\text { parts inside. }\end{array}$ \\
\hline $\begin{array}{l}\text { Hot Work } \\
\text { and rocesses }\end{array}$ & $\begin{array}{l}\text { Fumes and } \\
\text { gases }\end{array}$ & $\begin{array}{l}\text { - Welding areas require adequate ventilation and } \\
\text { local exhaust to keep fumes and gases from the } \\
\text { breathing zone and the general area. } \\
\text { - Hazardous substances are used incompliance with } \\
\text { MSDS. } \\
\text { - All welding operators should be aware that there } \\
\text { are ACGIH threshold limit values (TLV) and } \\
\text { OSHA permissible exposure limits (PEL) for the } \\
\text { substances in welding fume. } \\
\text { - To prevent exposure from coatings such as paint, } \\
\text { galvanizing, or metal platings on base metals, clean } \\
\text { the base metal before beginning to weld. }\end{array}$ \\
\hline $\begin{array}{l}\text { Workplace } \\
\text { and }\end{array}$ & $\begin{array}{l}\text { Falls, Slips } \\
\text { and Trips }\end{array}$ & $\begin{array}{l}\text {-Housekeeping is done on a daily basis to prevent } \\
\text { the walkways from being obstructed. }\end{array}$ \\
\hline
\end{tabular}




\begin{tabular}{|c|c|c|}
\hline $\begin{array}{l}\text { Working } \\
\text { Environment }\end{array}$ & & $\begin{array}{l}\text { - Spills or leaks are dealt with promptly. } \\
\text { - Storage area is separated from the workspace }\end{array}$ \\
\hline $\begin{array}{l}\text { Human } \\
\text { Factors }\end{array}$ & $\begin{array}{l}\text { Unsafe act } \\
\text { unsafe } \\
\text { Practices }\end{array}$ & $\begin{array}{l}\text { - Only people who are adequately trained or are } \\
\text { experienced and deemed as competent. } \\
\text { - Personal Protective Equipment is provided and } \\
\text { instructions on how to use them is provided as } \\
\text { easily understood, as well all workers are trained in } \\
\text { its proper use. } \\
\text { - Reactor is locked when not in use and only } \\
\text { accessed by authorised personnel who control the } \\
\text { keys to the reactor. } \\
\text { - electrical power is isolated when workshop is } \\
\text { closed and machinery controlled by keys. } \\
\text { - Avoid rolling up sleeves or pant cuffs, as sparks or } \\
\text { hot metal will deposit in the folds and may burn } \\
\text { through the material. Keep pants over the top of } \\
\text { work boots - don't tuck them in. } \\
\text { - Helmets with side shields are essential for } \\
\text { protecting eyes and skin from exposure to arc rays. } \\
\text { Make sure to choose the right shade lens for your } \\
\text { process - use the helmet's instructions to help select } \\
\text { the right shade level. } \\
\text { - To protect ears from noise, wear hearing } \\
\text { protection if working in an area with high noise } \\
\text { levels. Doing so will protect your hearing from } \\
\text { damage, as well as well prevent metal and other } \\
\text { debris from entering the ear canal. Choose ear plugs } \\
\text { or ear muffs to protect the ears. }\end{array}$ \\
\hline
\end{tabular}

\section{Discussion and results}

JHA ensure safe steps, teaches new workers, eliminates or controls hazardous materials. It is basic approach to developing incident prevention procedures. It can be a basic element in a safety program and the most effective safety programs are those that involve workers (8). Supervisors can use the findings of a job hazard analysis to eliminate and prevent hazards in their workplaces. This is likely to result in fewer worker injuries and illnesses; safer, more effective work methods; reduced workers' compensation costs; and increased worker productivity (9).

For a job hazard analysis to be effective, management must demonstrate its commitment to safety and health and follow through to correct any uncontrolled hazards identified. Otherwise, management will lose credibility and employees may hesitate to go to management when dangerous conditions threaten them. 
During the job review process, we especially focused on identifying hazardous conditions and unsafe behaviours. Identification of hazards in welding process provided to eliminate possible accidents during operations. if safety measures are ignored, welders face an array of hazards which can be potentially dangerous, including electric shock, fumes and gases, fire and explosions and more. Using JHA minimizes unsafe conditions and unsafe acts. After defined hazards, temporary and permanent precautions were taken. Proper personal protective equipment (PPE) are supplied against hazards of welding process inside reactor unit. All PPE are inspected before given workers. Welding workers are also trained about how work inside reactor unit. All hazards and precautions are taught.

\section{Disclosure statement}

No potential conflict of interest was reported by the author.

\section{Contact Information}

E-mail: hakand@yahoo.com 


\section{References and notes:}

Muhammad Arif, Gerry Silaban, Isyatun Mardiah Syahri, "Analisa Potensi Bahaya dengan Menggunakan Metode Job Safety Analysis (JSA) pada Proses Coal Chain di Pertambangan Batubara X Tahun 2014",

https://www.osha.gov/Publications/osha3071.pdf, accessed March 6, 2019.

James Roughton, Nathan Crutchfield, ' Job Hazard Analysis: A guide for voluntary compliance and beyond"'

Swartz George, Job hazard analysis . Professional Safety; Des Plaines Vol. 47, Iss. 11, (Nov 2002): 27-33.

John Ridley and John Channing, ,'Safety at Work "' Sixth edition

https://www.yamata.com.tr/en/projects/propane-dehydrogenation-unit-pdh-tobolsk/, accessed March 6, 2019.

https://www.rit.edu/ w-outrea/OSHA/documents/Module2/M2_JHA.pdf, accessed March 6, 2019.

Charles D. Reese, 'Occupational Health and Safety Management: A Practical Approach', https://www.safetyinfo.com/job-safety-analysis-jsa-safety-index/, accessed March 6, 2019. 